\title{
Espaço e distinção social: o catolicismo na Província de Sergipe ${ }^{1}$
}

Space and social distinction: Catholicism in the Province of Sergipe, Brazil

\section{Péricles Morais de ANDRADE JÚNIOR •}

Resumo: Este artigo tem como objetivo analisar as distinções sociais constituídas no catolicismo na Província de Sergipe Del Rey durante o século XIX. A análise está centrada nos critérios de admissão de duas irmandades religiosas atuantes na cidade de Estância. A pesquisa demonstra que havia uma população dividida entre as irmandades do Santíssimo Sacramento e de Nossa Senhora do Rosário, reflexos de uma hierarquia social mais diversificada, que diziam respeito a critérios de cor, riqueza e prestígio social. $\mathrm{O}$ espaço apresentava significados, na medida em que a cidade reproduzia simbolicamente a sociedade e sua organização em estratos sociais. Em outras palavras, observamos que o campo religioso católico na povoação de Estância seguia aos mecanismos de expressão da segregação e apresentava-se como representativo das oposições significativas entre os segmentos sociais, caracterizados a partir destas associações que definiam a posição social e os gostos dos seus integrantes.

Palavras-chaves: Irmandades religiosas; Distinção social; Sergipe.

Abstract: This article aims to analyze the social distinctions incorporated in the Catholicism in the province of Sergipe Del Rey during the nineteenth century. The analysis will be centered in the criteria of admission of two active religious brotherhoods in the city of Estancia in Sergipe, Brazil. The research shows that there was a population divided between the brotherhoods of the Blessed Sacrament and Our Lady of the Rosary, reflections of a more diversified social hierarchy about the criteria of race, wealth and social prestige. The space presented meanings in so far as the city reproduced, symbolically, the society and its organization in social strata. In other words, we notice that the Catholic religious field in the population of Estancia followed the mechanisms of expression of the segregation and presented itself as representative of the oppositions between the social groups, which were characterized by associations which defined the social position and the tastes of their members.

Keywords: Religious brotherhoods; Social distinction; Sergipe.

$\mathrm{Na}$ formação da sociedade brasileira a Igreja Católica teve um papel fundamental na configuração do espaço geográfico, guiando com a elevação de templos religiosos as diretrizes para o despontar e o transformar dos estabelecimentos urbanos. Essa importância estava relacionada com o próprio caráter da colonização lusa. Sendo assim, enquanto na porção hispânica havia um projeto que garantisse o predomínio metropolitano mediante a criação de grandes núcleos de povoação estável e bem ordenados, na América Portuguesa não existia esse interesse na efetivação de uma vida urbana.

Comparados aos espanhóis, os portugueses seriam diferentes quanto a predominância do caráter de exploração comercial e no que diz respeito a precariedade das suas vilas, daí a insistência da colonização litorânea. Dessa forma, por motivos estratégicos, os espaços urbanos criados pelos

\footnotetext{
- Professor Doutor - Departamento de Ciências Sociais e do Programa de Pós-Graduação em Sociologia - UFS - Univ. Federal de Sergipe - Rua Vereador Olímpio Grande, s/n, CEP: 49500-000, Itabaiana, Sergipe, Brasil. E-mail: periclesmorais@hotmail.com
} 
lusitanos se localizavam frequentemente em colinas e próximo ao mar (RAMINELLI, 1992, p.167). Nessas condições, as possibilidades da construção de uma intensa vida urbana tornavam-se difíceis. A obra realizada aqui no Brasil pelos portugueses possuiu mais um caráter de feitoração do que de colonização. Nesse sentido, não havia um projeto - como na América Espanhola - de ocupação dominante no espaço por parte do Estado Luso. Devido à falta de ordenamento estatal na formação e configuração do espaço urbano na luso-américa, coube à Igreja Católica, a partir da construção e posição geográfica de seus templos, ordenar o traçado dos núcleos de povoamento.

A partir do Padroado ${ }^{2}$ o cristianismo assumiu um caráter oficial nos domínios portugueses, onde a diferenciação entre o caráter religioso e o nacional praticamente não existia. Cristianizar uma região era acima de tudo, oficializá-la e reconhecê-la como um local onde o poder do Evangelho e o do Estado português se faziam presentes. Uma das formas desse domínio seria então a construção de uma capela, a qual possibilitaria aos moradores o reconhecimento por parte das autoridades. Desse modo, a formação de diversos povoamentos brasileiros esteve nos primeiros momentos ligada à construção de um templo católico. ${ }^{3}$

A importância alcançada pelos templos relacionava-se diretamente com os padrões determinados pelas autoridades eclesiásticas para a sua construção: estar situado no centro das sesmarias ou localidade afastada das demais construções e posta sobre um ádrio (área livre e sagrada). Os prédios religiosos eram peças importantes na encenação promovida pelo catolicismo, pois reafirmavam diariamente o contato entre o sagrado e os homens. A visualização de igrejas e capelas, somadas à encenação do culto católico, forneciam oportunidade de aproximação de Deus com os mortais (RAMINELLI, 1992, p.172).

A visualização dos templos católicos na paisagem luso-brasileira significava, nesse sentido, a sacralização de uma região. Aqui o sagrado se opõe ao profano. Mais precisamente, é marcada a distinção entre "espaço sagrado" e "espaço profano". Dito de outro modo, a construção dos templos católicos implicava na visão do fiel em relação a sacralização dos espaços e a fundação do mundo em um novo tempo no qual a experiência do sagrado tornasse possível a "fundação do Mundo": lá onde o sagrado se manifesta no espaço, o real se revela, o Mundo vem à existência. Como afirma Mircea Eliade, todo o mundo é obra dos deuses, porque foi criado diretamente pelos deuses e consagrado ("cosmizado") pelos homens, ao reatualizarem ritualmente o ato exemplar da Criação. Em suma, essa nostalgia religiosa exprime "o desejo de viver num Cosmos puro e santo, tal como era no começo, quando saiu das mãos do Criador" (ELIADE, 2001).

Esses elementos seriam determinantes na configuração urbana do povoamento em formação, pois com um templo católico ao centro o espaço seria traçado a partir deste ponto de referência. Os templos deveriam ser os primeiros objetos percebidos ao longe, símbolos de poder, orgulho e ostentação dos habitantes. Isso fazia com que nas povoações sobressaíssem por sua imponência as 
construções eclesiásticas, em que "o contraste era flagrante, pois o estilo das residências revelava-se pobre e sem gosto, e as igrejas e conventos se destacavam pela posição privilegiada, volume e solidez”. O aproveitamento e a divisão das terras que compunham desenharam, de forma paulatina, a característica dos arraiais (HAUCK, 1992, p.54).

A partir das doações dos habitantes da região formava-se o patrimônio da capela, principalmente dos sesmeiros (que futuramente estariam situados em volta da capela construída) ou das irmandades religiosas, que representavam os segmentos sociais. Esse financiamento por parte dos leigos relacionava-se a elementos devocionais da sociedade colonial, em que a população sentia-se lisonjeada com o esplendor, a grandiosidade e a riqueza das igrejas. A sensação exposta estava relacionada com a devoção, o alcance de graças, o reconhecimento e a crença de que a riqueza era patrimônio de todos os fiéis. O esplendor de uma igreja significava para uma região o cumprimento da fé, a exaltação do poder católico e da sua gente.

Diversas formas foram utilizadas para o requerimento de recursos para as obras dos templos. $\mathrm{Na}$ construção do espaço, havia a presença de um caráter material e simbólico que, consequentemente, vinculava-se ao grupo social que financiava, ocasionando prestígio e controle por parte desses segmentos. Doar terras, animais, escravos, entre outros bens, poderia significar para um senhor de engenho ou uma irmandade, o respeito e o reconhecimento dos habitantes da região, do Clero e do Estado.

Aos poucos a Igreja Católica tornou-se possuidora de vastos terrenos provenientes dessas doações, heranças e promessas dos fiéis. Para a população, todo o patrimônio não pertencia aos componentes do clero (mas aos Santos e Santas) e eram administrados frequentemente por leigos. Isso não impedia que, em alguns momentos, o terreno fosse cedido para usufruto de quem o pedisse, pois não se cultivavam em nome da Igreja Católica e sim, dos Santos Padroeiros.

Entretanto, não bastava apenas erguer a ermida; não bastava construir, por melhor que fosse, uma capelinha; era necessário oficializá-la. Isso tinha grande peso, pois a institucionalização da vida na comunidade perante as autoridades devia-se através da oficialização de sua ermida, de sua capelinha ser visitada por um cura, pela sua elevação um dia a matriz, elevação que significava a ascensão de toda uma região inóspita, ou de ocupação mais antiga e em expansão, ao novo status de paróquia da freguesia (MARX, 1991, p.18).

Com a oficialização, a localidade seria reconhecida pelas autoridades e, consequentemente, ganharia novas feições urbanas, principalmente após a elevação à freguesia. Prosseguia-se o desenvolvimento da nova sede, ocasionado no aumento do número de lares, negócios e na ampliação do adro. Esse deveria tornar-se embelezado e regularizado para compor o largo da nova sede paroquial ou igreja matriz. A nave do templo alcançava "status" religioso, aumentando o prestígio, ocasionando alterações para que o prédio abrigasse novas funções e dignidades devidas. 
Após o reconhecimento, a antiga capelinha tornava-se referência para caracterizar a elite da região, que se fazia presente com novas doações, fazendo com que todos os esforços se voltassem para ela, tornando-se sinônimo de enaltecimento da comunidade em ascensão.

Além de possuir a função de centro religioso para um vasto território, a igreja era lugar de encontro e de longas conversas, mesmo quando estava exposto o Santíssimo Sacramento (HOONAERT, 1992, p.296). Os templos religiosos constituíam-se no espaço do cumprimento das obrigações católicas e ao mesmo tempo, nas festas, nas discussões, ou seja, quando a vida festiva da população era efetivada num entrelaçamento entre o sagrado e o profano. Onde o povo aproveitava o raro momento do encontro para a troca de notícias (MARX, 1991, p.116).

\section{Distinção social e irmandades religiosas}

$\mathrm{Na}$ frequência das missas e festas a distinção social se fazia presente na configuração espacial do interior das igrejas. Havia uma situação de hierarquização e discriminação, agravando-se na medida em que a aglomeração urbana tornava-se maior e, consequentemente, a igreja passava por reformas. Nessa sociedade estratificada - na qual a própria organização do espaço demonstrava a segregação - dava-se a apropriação do campo religioso por parte dos segmentos dominantes, criando mecanismos de separação, identificação e ajuda mútua, como as irmandades, uma das formas mais expressivas da configuração simbólica e social dos espaços religiosos brasileiros. Tendo sua origem na baixa Idade Média, as irmandades tiveram seu nascimento e inspiração relacionado à égide do poder espiritual. Nesse período as inseguranças e incertezas levaram os homens a unir-se em torno de associações voluntárias, daí originando uma proliferação de confrarias de auxílio mútuo.

O auxílio seria adquirido através do cumprimento das obrigações, que consistiria em benesses e segurança indispensável para os tempos de doença, invalidez e sepultamento. As irmandades tornaram-se, com o tempo, o canal de manifestação de seus membros, o veículo de suas queixas, o palco de suas discussões. Sendo assim, essas associações, ao desenvolverem inúmeras tarefas, constituíram uma força auxiliar, complementar e substituta da Igreja Católica e do poder público (BOSCHI, 1986, p.13-14).

No Brasil, as irmandades surgiram a partir das reminiscências das antigas corporações de artes e ofícios. O primeiro objetivo era congregar um número de fiéis em torno da devoção de um santo escolhido como padroeiro. Elas eram baseadas no 'compromisso', que consistia num conjunto de regras submetidas desde logo à aprovação do rei e que determinava os objetivos da associação, as modalidades de admissão de seus membros, seus deveres e obrigações ${ }^{4}$. Após a aceitação do 
compromisso, os membros se comprometiam a venerar o santo padroeiro, manter seu culto e promover sua festa (MATOSO, 1997, p.397).

Entretanto, no decorrer dos períodos colonial e imperial no Brasil, as irmandades também assumiram o caráter associacionista. Dessa forma, foram conferidos aos leigos a responsabilidade de se destacarem pelo oferecimento à Igreja Católica da promoção das devoções e pelo eficiente instrumento material de sustentação do culto, fazendo-se presentes no cotidiano das festividades religiosas. Pode-se dizer que o catolicismo era, no Brasil, uma organização de leigos (HAUCK, 1992, p.13).

A construção dos templos por parte das irmandades obedecia a elementos de diferenciação, apontados anteriormente quando enfocamos a configuração do espaço dentro das igrejas. Num universo estratificado, os interesses de brancos, pretos e pardos eram conflituais. Sendo assim, a configuração da posição geográfica dos templos relacionava-se ao caráter simbólico em que estava vinculado o grupo e representava as disputas pelo controle da hegemonia do campo, como destaca João José Reis: “os templos que ocupavam representavam um marco fundamental de identidade, pois neles não funcionava, em princípio, mais de uma confraria com o mesmo nome” (REIS, 1991, p.49)

Impedidos de frequentar os espaços centrais, os grupos sociais discriminados e suas respectivas irmandades foram obrigados a construírem novos espaços religiosos, contribuindo, dessa forma, para a proliferação dos templos no Brasil-Colônia e Império ${ }^{5}$. Com isso, configuravase um espaço simbólico que teria ao centro a Igreja da Matriz - sede da Irmandade do Santíssimo Sacramento, por exemplo - e outras periféricas - sede de outras associações como a Irmandade do Rosário dos Negros.

A topografia nas cidades brasileiras representava a manifestação da segregação social na posição dos templos. Configuravam-se na sociedade diversos mecanismos de expressão sóciosimbólica, representativos das oposições significativas entre os agentes sociais, que corresponderiam a estilos de vida, sistemas de desvios diferenciais que eram a retradução de diferenças objetivamente inscritas nas condições de existência.

Seriam através das irmandades religiosas que os segmentos sociais apresentavam o seu estilo e gosto de vida, e tomariam posições diante de uma sociedade segregada via controle e frequência do campo religioso. Na sociedade brasileira a configuração urbana seria marcada a partir da diferenciação religiosa dos grupos e das suas tomadas de posição.

Na Freguesia de Nossa Senhora de Guadalupe de Estância na Província de Sergipe esses elementos encontravam-se presentes na localização e significado simbólico das suas igrejas e nos agentes sociais que as frequentavam. As disputas pelo controle do campo religioso se daria entre as 
irmandades do Santíssimo Sacramento e de Nossa Senhora do Rosário e seus respectivos subespaços.

\section{Os subespaços católicos}

O atual município de Estância - localizado na região centro-sul do Estado de Sergipe - teve a sua formação urbana relacionada à construção da capela de Nossa Senhora de Guadalupe, situada ao centro de um conjunto de sesmarias. Em 1621, seguindo a ocupação de Sergipe Del Rey no sentido Rio Real - Vaza-Barris, Pedro Homem da Costa e Pedro Alves solicitavam à Coroa a posse de terras devolutas existentes na região que haviam sido ocupadas pelo seu sogro João Dias Cardoso. Como um grande número das primeiras sesmarias em Sergipe não havia sido de fato ocupadas, estabeleceu-se uma segunda distribuição. Nesse caso, transferiu-se o controle do lote para os genros do primeiro sesmeiro.

Justamente nas terras dos respectivos sesmeiros foi erguida a primeira igreja da futura povoação de Estância. Através da doação do terreno por parte de Pedro Homem da Costa e sua mulher Méssia Cardosa, iniciou-se a construção da capela que se destinava ao culto de Nossa Senhora de Guadalupe. ${ }^{6}$

Dizem pedro homem da costa e pedro alves ambos cu- nhados moradores nesta capitania que a muitos anos que nella sam moradores com suas molheres e filhos e nella em todas as occazioins que se ofereseram do serviso de sua magestade se acharão com suas armas e cavalos e escravos e com muitos negros da terra e com toda a mais fábrica que tem e pressumien e porque pera seus gados e outras criasions que tem não pastos nem matos para comerem e uns escravos fazerem rozarios de mantimentos e prantarem can- nas e algodão e pretenderem fazer engenhos [...] (Apud. SANTOS, 1988, p.05).

Interessa-nos analisar alguns elementos que encontram-se presentes neste documento. $\mathrm{O}$ primeiro seria a participação leiga na construção dos templos católicos, tão comum no BrasilColônia. Como indicamos, cabia ao Padroado a função de erguer igrejas e com isso levar a fé e a presença do cristianismo em todo o território português. Contudo, diante da deficiência administrativa e financeira, a função fora aos poucos exercida pelos leigos. Esta afirmativa relaciona-se com a Igreja de Nossa Senhora de Guadalupe, na medida em que sua criação deu-se a partir da iniciativa do sesmeiro e da sua mulher. Através da doação de quinhetas braças de terras e de diversos outros bens (seis vacas e um touro), iniciava-se a formação do patrimônio religioso da Capela, que seria constituído de terras e de instrumentos que deveriam ser utilizados para a sua ornamentação e manutenção. 
Outro elemento que poder ser apontado na carta constitui-se na necessidade devotiva e, ao mesmo tempo, de reconhecimento por parte do doador. Com a criação da dita Capela, o Sesmeiro teria a sua devoção contemplada com um espaço sagrado que poderia, inclusive, significar o reconhecimento da região e no qual seriam administrados os Sacramentos Divinos, a bem serviço de Deus. Em outras palavras, com a Capela a região se tornaria um local cristão, oficial em que o poder português se fazia presente.

A Capela foi construída num dos pontos mais elevados da região, fazendo com que a dita igreja fosse um dos primeiros objetos vistos de longe, símbolo da presença do poder cristão e do Estado português. Segundo José Anderson do Nascimento, pelo estilo arquitetônico podemos constatar que a construção do templo atual teria sido entre fins do século XVII e começo do XVIII, e concluídas em meados do Setecentos (NASCIMENTO, 1981).

O estado físico dos templos católicos significava a decadência ou ascensão das suas respectivas localidades. No caso de Estância, as condições da Capela de Nossa Senhora de Guadalupe constituíram um parâmetro para caracterizar o seu desenvolvimento, assim como, reconhecê-la e ressaltar a possibilidade de se ministrar os "Divinos Sacramentos". 7

Com esses dados podemos concluir que já no início do século XVIII a Capela de Nossa Senhora de Guadalupe possuía grande importância para a região, tornando-se um centro religioso para os seus habitantes e um referencial para caracterizar o progresso da povoação. Isso pode ser constatado através de diversas descrições sobre a localidade, como a apresentada por Marcos Antônio de Sousa, em 1808: “em uma praça quadrilonga da sobredita povoação existe uma Capella magestosa de Nossa Senhora de Guadalupe, onde se administram os sacramentos aos circuvizinhos da referida povoação" (SOUSA, 1918, p.23).

Essa característica de grandisiosidade e esplendor fez com que a Capela alcançasse um grande status, mesmo antes da sua elevação à freguesia - que só ocorreu em 1831. A Igreja de Guadalupe tornou-se aos poucos um centro de referência para toda a região, inclusive, sobrepondose ao templo religioso da Vila de Santa Luzia do Itanhy. Desse modo, acreditamos que esse espaço constituía-se no local de cumprimento das obrigações religiosas dos fiéis, das festividades, conversas e encontros não apenas da povoação de Estância, mas de todas as outras localidades circunvizinhas, como a própria Vila de Santa Luzia, o arraial de Espírito Santo (atualmente Indiaroba) e o de Riacho da Guia (atualmente Umbaúba).

Nesses momentos de encontro operava-se a segregação. Não temos documentos manuscritos que confirmem, contudo, a partir da estrutura arquitetônica da igreja, podemos supor que durante as missas havia distribuição das posições entre os segmentos presentes na sociedade estanciana. Além dessa distribuição sócio-espacial nas missas e festas, outro mecanismo foi criado, fazendo com que os segmentos dominados fossem aos poucos afastados da sua frequência e do controle do espaço. 
Esse foi a Irmandade do Santíssimo Sacramento, que havia instalado a sua sede no templo em $1847^{8}$. Para uma melhor compreensão dessa afirmativa, faz-se necessária uma apresentação e análise do seu Estatuto.

Segundo Eduardo Hoonaert, no Brasil a finalidade específica dessa irmandade era a promoção do culto do Santíssimo Sacramento. Os seus objetivos básicos eram a prática de todas as "virtudes morais e religiosas", a devoção ao culto do Santíssimo Sacramento e a organização das festas de Corpus Christi e da Semana Santa. É uma das irmandades mais antigas e mais difundidas no período colonial e imperial. Todavia, como a Irmandade da Misericórdia, sua atuação se restringia aos centros urbanos, onde era possível a presença do sacerdote para a celebração da missa e consagração da hóstia, que permitisse o culto eucarístico" (HOONAERT, 1992, p.237).

Nos centros urbanos sua vinculação era restrita aos homens e congregavam em geral figuras da elite local. Promoviam a maior procissão celebrada durante todo o ano, a do Corpo de Deus. Seus componentes vestiam roupa vermelha durante o culto e carregavam tocha nas procissões eucarísticas (PRIORE, 1994, p.41). A Irmandade do Santíssimo Sacramento de Estância diferenciava-se apenas em um aspecto: admitia pessoas de ambos os sexos. Entretanto, o caráter discriminatório estava presente em diversos momentos, regulamentado inclusive, pelo Estatuto aprovado em 18 de fevereiro de 1848.

Em relação às garantias para os Irmãos, era oferecido socorro pecuniário e mensal na vida. Na morte, caixão, acompanhamentos e encomendação do pároco. Garantia-se aos vivos e mortos:

- As missas de todas as quintas-feiras do ano com música, havendo devotos que toquem e cantem grátis.

- Todas as solenidades, e mais atos das festas de Corpus Christi e Semana Santa.

- Todos os atos de religião e caridade, que em benefício da humanidade ou de irmão em particular se fizerem à custa da Irmandade do Santíssimo Sacramento.

- Missas pelos padres assistentes ao $2^{\circ}$ até o $8^{\circ}$ dia da comemoração geral.

Segundo o Estatuto, para ser considerado irmão da irmandade era necessário:

- Ter boa conduta moral e ser Católico Apostólico Romano.

- Ser branco. ${ }^{9}$

- Ter meios de subsistência.

- Estar no gozo e administração de seus bens: excetua-se a casada, com filho, família ou tutelada, que podem ser admitidos com o consenso do marido, pai ou tutor (APES, AG4, caixa 12, doc. 137, Correspondências, 10/08/1853). 
A Irmandade do Santíssimo Sacramento sobrevivia à custa dos pagamentos de anuais dos Irmãos, que eram denominados Efetivos (tinham a obrigação de pagar empregos, aceita-los e a pagar anuais) e os Honorários (poderiam ser os moradores de outras freguesias e os temporários, os maiores de 50 anos, os admitidos por moléstia grave e os atuais reunidos). Havia uma série de procedimentos que deveriam ser obedecidos pelos integrantes e que caracterizavam a situação dos mesmos perante o grupo. Atribuía-se grande importância aos elementos materiais na definição da posição e titulação do indivíduo, reconhecido de acordo com a quantia do pagamento efetuado:

* Simples: aquele que tinha concorrido com a entrada, anuais e jóias do grau mínimo. As doações em dinheiro deveriam ser acima de cento e cinquenta mil réis.

* Distinto: aquele que tinha concorrido acima de trezentos mil réis.

* Honorífico: aquele que tinha concorrido com seiscentos contos de réis.

* Protetor e Honorífico: aquele cujas ofertas excediam um conto de réis.

* Benfeitor: aquele com doações de dous contos de réis.

Em diversos momentos foi comum a cobrança por parte do tesoureiro de anuais atrasados à família de um irmão falecido, especificamente no momento de elaboração do inventário. ${ }^{10}$

A partir dos elementos expostos referentes ao Estatuto, podemos constatar o caráter discriminatório da Irmandade do Santíssimo Sacramento, tendo como critério para o reconhecimento e aceitação, a condição branca e de senhor de posses. Mesmo no seu seio, a posição do indivíduo seria definida através da contribuição financeira, principalmente na ocupação dos cargos mais relevantes. Assim, para Juiz era necessário "ser um irmão abastado", Tesoureiro "irmão possuidor de bens" e Procurador "pessoa acreditada" (Compromisso da Irmandade do Santíssimo Sacramento de Estância. Capítulo XI, art. Acervo da Associação).

Dessa forma, podemos afirmar que a Irmandade do Santíssimo Sacramento aqui analisada constituía-se numa entidade elitista, o que confirma a informação apontada por Hoonaert (1992) no tocante ao quadro brasileiro. Essa condição elitista era definida através dos requisitos de aceitação e reconhecimento do indivíduo, ou seja, de uma série de condutas e posições que definiam o seu habitus (BOURDIEU, 1996), o qual era determinado pela condição de cor (branca) e financeira (posses). Na medida em que a dita irmandade possuía o controle do subespaço da Igreja de Nossa Senhora de Guadalupe, institui-se nessa o caráter simbólico da elite, segundo o qual não havia a aceitação num mesmo subespaço dos outros segmentos da sociedade estanciana, em suma, os nãobrancos e despossuídos. Em suma, a partir da importância atribuída à edificação majestosa e pelos elementos supracitados característicos da irmandade, podemos concluir que a matriz assumiu uma feição elitista em meados do século XVIII, configurando-se no subespaço religioso privilegiado dos segmentos dominantes. 
Impedidos de frequentar e, ao mesmo tempo, utilizar esse local como referência, os outros segmentos sociais foram obrigados a construir um novo templo, o qual deveria abranger seu estilo de vida e os torná-los visíveis. Desse modo, foi erguida a Igreja de Nossa Senhora do Rosário, localizada quase um quilômetro do centro da povoação.

Enquanto que a Igreja de Nossa Senhora de Guadalupe teve sua origem relacionada ao primeiro tipo de templo católico da colônia - em que sua localização deveria estar ao centro de um conjunto de sesmarias e posteriormente a sede da Irmandade do Santíssimo Sacramento, espaço de referência para a elite local - a capela de Nossa Senhora do Rosário fora erguida após a criação da irmandade do mesmo nome. Destarte, sua história nos primeiros momentos e durante todo o século XIX confunde-se com a da referida irmandade. Esse tipo de associação leiga difundiu-se pelo Brasil desde o século XVI, com a finalidade de promover a elevação do rosário de Nossa Senhora. Seus irmãos cuidavam do altar e promoviam a festa de Nossa Senhora do Rosário, celebrada em outubro. Os componentes rezavam o terço na rua com uma procissão mensal ou semanal, seguindo todos atrás do painel do terço. Admitiram no início elementos de todas as raças, entretanto, com o tempo passaram a ter participantes apenas negros (HOONAERT, 1992, p.237-238).

Na sociedade brasileira colonial e imperial, o negro era considerado um “infiel”. Sua própria condição de cor e raça transmitia um significado de pecado e desqualificação cultural e religiosa. ${ }^{11}$ A participação em atividades na Igreja era uma forma de promoção social, um certo acesso ao mundo dos brancos. Era nas procissões e festas religiosas que os escravos podiam "brincar" a vontade, dançar, soltar fogos, disfarçar-se e imitar os brancos, contudo dentro da hierarquia global (HOONAERT, 1991, p.73).

As irmandades religiosas constituíam-se num importante instrumento de expressão do mundo africano sob símbolos cristãos, além de ter um papel primordial na inserção e reconhecimento do negro (FRAGOSO, 1992, p.147). Em síntese, essas associações contribuíram para aumentar o sincretismo religioso, aproximando crenças e cultos. Tornaram-se, aos poucos, mecanismos de defesa e proteção dos negros contra a escravidão, permitindo-lhes canalizar suas agruras, expressar suas necessidades. Através da associação, negros e mulatos tinham socorro diante das doenças, miséria, abandono ou quando desejavam conseguir liberdade sem fugir - as irmandades em algumas ocasiões juntavam dinheiro para alforriar seus irmãos (PRIORE, 1994, p.39).

Esses elementos encontravam-se presentes na povoação de Estância com o surgimento da Irmandade de Nossa Senhora do Rosário na segunda metade do século XVIII. Sua formação é anterior a 25 de dezembro de 1772, quando é fundada oficialmente. Entretanto, o Compromisso só foi aprovado em 1843. Isso ocorreu porque até o fim do período colonial o documento era enviado à Portugal para aprovação do rei. Acreditamos que devido à burocracia, o Compromisso fora reconhecimento depois de 71 anos de funcionamento da irmandade (Apud. SANTOS, 1992, p.73). 
Em 1780 ocorreu a união com a Irmandade de São Benedito. Essa junção foi comum, sobretudo, entre as irmandades pobres que enfrentavam dificuldades para sobreviverem independentes e devido ao parentesco dos Santos padroeiros de negros. São Benedito, Santa Efigênia e Nossa Senhora do Rosário eram invocações dos negros não apenas pela afinidade epidérmica ou pela identidade de origem, mas por seus agouros. Os “santos dos brancos' — supunha-se — não saberiam compreender os dissabores e os sofrimentos dos negros.

No início, a Associação era composta por: 70 homens, 35 mulheres, 47 escravos, 52 livres e libertos. $\mathrm{O}$ caráter heterogêneo estava vinculado à inserção dos brancos nas irmandades de negros. Enquanto o ingresso de "pretos" era proibido nas outras associações (como no caso da Irmandade do Santíssimo Sacramento aqui apresentada), os brancos conseguiram impor-se nas confrarias tidas como de negros. Principalmente por tratar-se de escravos, não possuíam personalidade jurídica e, portanto, não podiam responder pela administração da entidade. Isso não elimina a possibilidade de irmandades compostas somente por negros ou que estes exercessem os cargos mais importantes. Contudo, constituíam casos raros, como a Irmandade do Rosário da Freguesia de Vila Nova de Sergipe Del Rey. Sendo assim, na composição dos cargos havia a diferenciação entre os elementos de cor.

Além desse obstáculo jurídico, os senhores não viam com bons olhos o controle de um instrumento financeiro tão poderoso - como as irmandades - em mãos de negros escravos ou libertos. Segundo Julita Scarano, "ficava muito mais fácil controlar de dentro" (SCARANO, 1978, p.131).

Outra característica da Irmandade de Nossa Senhora do Rosário de Estância era a procedência dos brancos que compunham seus quadros. Como vimos, uma das exigências de admissão na Irmandade do Santíssimo Sacramento era a posse de bens. Desse modo, os indivíduos brancos que se faziam presentes na fundação da Irmandade do Rosário não compunham, na sua maioria, os setores da elite da povoação.

O caráter discriminatório entre brancos e negros também é observado no calendário religioso da irmandade. Havia duas festas: uma no primeiro domingo de outubro organizada por brancos, data oficial de Nossa Senhora do Rosário no calendário da Igreja, essa festividade seguia todos os moldes do catolicismo oficial, e a outra organizada por negros, correspondia ao sexto dia de Janeiro com o festejo dos Reis Magos. Neste, havia o sincretismo religioso identificado pela coroação dos chamados Reis do Congo. ${ }^{12}$

Além desse aspecto ligado à produção agrícola, a divisão relacionava-se ao caráter étnico/social dos irmãos. Como a Associação possuía livres, supostamente brancos, e escravos, evidentemente negros, os primeiros detinham a prerrogativa de comemorar na data oficial, primeiro domingo de outubro e os segundos, em dezembro ou janeiro. 
Uma das finalidades dessa irmandade era a construção de um templo destinado ao culto de Nossa Senhora do Rosário onde estaria sua sede. ${ }^{13}$ A sobrevivência da irmandade dava-se através de jóias, taxa anual, doações e aluguéis. Como o financiamento para as obras de uma Capela requeria muitos recursos e tendo em vista as dificuldades da Associação, tornou-se evidente a necessidade de ajuda de alguns fazendeiros da região, que ofereciam como "jóias" casas, terrenos, entre outros imóveis. ${ }^{14}$

Formou-se então o patrimônio da irmandade e arrecadou-se fundos para erguer a Capela, tendo sido iniciada a construção antes dos registros oficiais da irmandade. Assim como ocorreu com a Igreja de Nossa Senhora de Guadalupe, também a Igreja do Rosário teve um longo período para o término das obras, principalmente por depender das doações dos Irmãos.

Sendo assim, a sua edificação obedeceu a um período de cerca de setenta anos, tendo as seguintes etapas: em 1788 o seu retábulo foi concluído; em 1799 a parte lateral; em 1808 o corpo da igreja; em 1831 o frontifício e as torres, em 1841 o Adro. "Escolhido o local, foi construída uma pequena ermida, tendo a sua frente um Cruzeiro com cofre para doações. Aos poucos ia-se aumentando a construção." Seguindo a mesma prática da Irmandade do S. Sacramento, a Irmandade do Rosário utilizava-se da cobrança de pagamentos às famílias dos irmãos falecidos, através de petições enviadas ao Juiz de Orfãos da Freguesia (AJES, Fundo: C. Est. 2 ofício; Série: Diversificada; Sub-série: Petição; N. ${ }^{\circ}$ da caixa: 03, 31/07/1843).

Durante o século XIX tais instituições leigas foram progressivamente marginalizadas, desapropriadas das suas funções de administração das capelas e cemitérios. Aos poucos, o poder decisório das Mesas das confrarias passou para as mãos do vigário (GAETA, 1997). Através dessa destituição do capital dos leigos, o clérigo investia-se de autoridade, tornando-se o exclusivo responsável por atividades reservadas ao laicato. Num primeiro momento, a estratégia utilizada pela hierarquia para essa desapropriação se deu com a intervenção direta nos negócios das irmandades e confrarias. Em seguida foram instituídas novas associações, controladas e submissas ao clero, como o Apostolado da Oração e a Pia União das Filhas de Maria.

Em relação à primeira estratégia, caso ilustrativo ocorreu na Freguesia do Sagrado Coração de Jesus, na cidade de Laranjeiras. Em 1883 faleceu o Capitão Antonio José do Valle Marafuz. Membro da Irmandade do Senhor do Bonfim, o militar tinha direito às exéquias concedidas pela irmandade aos irmãos falecidos, assim como espaço reservado no cemitério do Bonfim, administrado pela dita associação. Entretanto, o vigário da Freguesia, Eliziário Vieira Muniz Telles, proibiu o Provedor da irmandade de praticar tal sepultamento. De acordo com o padre, os sentimentos do falecido eram "inteiramente contrários a Religião Catholica", pois declarava publicamente que não acreditava nos Sacramentos da Igreja Católica e blasfemava furiosamente contra o Pontífice Romano. Era um "herege publico", não tendo se reconciliado com o catolicismo 
nem ao menos na hora extrema. Desse modo, não tinha direito à sepultura eclesiástica (Ofício do Vigário Eliziario Vieira Muniz Telles ao Presidente da Província de Sergipe del Rey. Laranjeiras, 17 abr. 1883. APES, Ag4-clero, cx. 28, doc. 034.)

Diante da proibição, o sobrinho do falecido, Vergilio do Valle Vianna, enviou correspondências ao vigário e ao Provedor da irmandade. Nesses documentos, Vergilio afirmava que seu tio tinha direito a uma sepultura, pois foi aceito pela Irmandade do Bonfim. Admitia a negação das exéquias, afirmando que o cadáver nada queria da Igreja Romana, isto é, "água benta e incenso", e sim, o "logar a que tem direito no cemiterio d'aquella confraria...", direito decorrente das jóias pagas (Ofício de Vergilio do Valle Vianna ao Vigário Eliziario Vieira Muniz Telles. Laranjeiras, 15 abr. 1883. APES, Ag4-clero, cx. 24, doc. 034; Ofício de Virgilio do Valle Vianna ao Provedor da Irmandade do Senhor do Bonfim. Laranjeiras, 15 abr. 1883. APES, Ag4-clero, cx. 28, doc. 034.).

O impasse ocasionou a invasão do Cemitério do Bonfim por um grupo de homens durante a noite, que efetuaram o sepultamento do "a-catholico" Capitão Marafuz". Diante do problema, o vigário solicitou ao Presidente da Província providências para que isso não se repetisse, como havia acontecido com o seu antecessor no Cemitério da Misericórdia (Ofício do Vigário Eliziario Vieira Muniz Telles, ao Presidente da Província de Sergipe del Rey. Laranjeiras, 17 abr. 1883. APES, Ag4-clero, cx. 28, doc. 034.).

O episódio relatado ilustra a intromissão do clero nas esferas das irmandades religiosas. A argumentação do vigário para proibir o sepultamento apresenta critérios de definição dos membros no campo católico sergipano. O aparelho eclesiástico exercia o papel de registro civil, conferindo aos indivíduos o reconhecimento social por seu estado. Eram o batismo, o Matrimônio e o funeral religioso que davam o reconhecimento social ao nascimento, ao casamento e à morte do indivíduo. Do nascimento até morte, a vida tinha que passar pela Igreja Católica, independentemente da fé do indivíduo. Mesmo um "não-crente” tinha que comportar-se como católico para viver em sociedade (OLIVEIRA, 1985, p.155).

Sendo um indivíduo que não possuía um habitus reconhecido, Marafuz não tinha direito a uma sepultura num espaço sagrado. Dessa forma, o vigário interferiu nos negócios da Irmandade do Bonfim, estabelecendo critérios de conduta aos seus irmãos, prática que antes era definido pelos seus próprios membros. Em outras palavras, essa desapropriação marginalizou tais leigos das tarefas de decidir e legislar sobre quem deveria ser aceito pela sua respectiva irmandade e sobre o controle dos seus rituais e espaços (CASTILLO, 1997, p.111). 


\section{Configuração do caráter social do espaço católico}

Como pode ser percebido, constituía-se uma população dividida entre as irmandades religiosas, reflexos de um hierarquia social mais diversificada, que diziam respeito a critérios de cor, riqueza e prestígio social. Desse modo, o espaço apresentava significados, na medida em que a cidade reproduzia simbolicamente a sociedade e, sua organização em classes. Em outras palavras, observamos que o campo religioso católico na povoação de Estância seguia aos mecanismos de expressão da segregação e apresentava-se como representativo das oposições significativas entre os segmentos sociais, caracterizados a partir dessas associações que definiam a posição social e os gostos dos seus integrantes.

Havia nesses dois subespaços, definidos a partir de um conjunto unitário de preferências distintivas que exprimiam, na lógica específica de cada um dos subespaços simbólicos, categorias sociais e étnicas, que caracterizavam o estilo de vida dos respectivos irmãos. Com isso, as atitudes, as formas de praticá-la, opiniões, maneira de expressão e consumo dos membros da Irmandade do Sacramento diferenciavam-se daqueles da Irmandade do Rosário. Essas diferenças associadas a posições funcionavam como constitutivas de sistemas simbólicos. A forma de se vestir, as festas, a localização e esplendor dos espaços, e a expressão da religiosidade, formavam um sistema mítico, isto é, signos distintivos.

Os componentes da Irmandade do Sacramento a partir da posição da sua igreja-sede e do Estatuto ocupavam o pólo central por possuir um máximo de capital social e por seu caráter étnico, constituindo-se no grupo denominado por ortodoxo. Em segundo plano, a periferia era definida pelos irmãos do Rosário, caracterizados com a ausência ou raridade de capital social, os heterodoxos. A disputa no campo católico se fazia presente em Estância a partir da posição das igrejas, dos segmentos que possuíam o controle do campus e da expressão do seu hábito, configurava-se na sociedade estanciana dois subespaços socialmente e simbolicamente definidos. Duas realidades díspares: uma igreja central, sede de uma irmandade da elite daquela sociedade e outra periférica, sede de uma irmandade de livres, escravos e libertos.

$\mathrm{O}$ universo social acima descrito se constitui naquilo que Danièle Hervieu-Lèrger (2005) denomina de "civilização paroquial”. Nessa o "praticante regular" continua a ser a figura típica do mundo religioso estável, onde a vida religiosa organizada em torno do campanário regia os espaços e o tempo, onde o padre, inteiramente consagrado à gestão das coisas sagradas, exercia sem partilha a autoridade sobre os fiéis, cuja submissão à instituição media a implicação espiritual. As figuras dos praticantes regulares correspondem a um período típico do catolicismo, marcado pela extrema centralidade do poder clerical e pela forte demarcação territorial das pertenças comunitárias. Isto se 
evidencia nos pertecimentos aos dois subespaços católicos identificados a partir da suas respectivas irmandades: Santíssimo Sacramento e do Rosário.

A partir dos dois habitus instituídos pelas duas irmandades religiosas eram constituídas matrizes geradoras que estavam associadas à existência de identidades religiosas fortemente constituídas, que definiam dois grupos de crentes socialmente identificados como "comunidades". Nesse caso, aquela em volta da Igreja de Nossa Senhora de Guadalupe e a outra em torno da Igreja de Nossa Senhora do Rosário. Cada tradição constrói a figura do "praticante" que lhe é própria e que articular uma crença e uma pertença comunitária inscrita num ritual e em práticas particulares, conforme vimos na análise dos traços distintivos estabelecidos pelas duas irmandades. As figuras emblemáticas dos "praticantes" é o que manifesta na vida comum o laço que existe entre crença e pertença. Elas estão associadas à estabilidade das identidades religiosas e à permanência das comunidades nos seio das quais essas identidades se transmitem e exprimem. É esse ideal da participação religiosa que, hoje em dia, se confronta com a mobilidade das pertenças, a "desterritorialização" das comunidades, a desregulação dos processos da transmissão religiosa e o individualismo das formas de identificação (HERVIEU-LEGER, 2005).

\section{Referências Bibliográficas}

BOURDIEU, Pierre. Razões Práticas: sobre a teoria da ação. Campinas: Papirus, 1996.

. A Economia das Trocas Simbólicas. 5.ed., São Paulo: Perspectivas, 1998.

. O Poder Simbólico. 2.ed., Rio de Janeiro: Bertrand Brasil, 1998-b.

BOSCHI, Caio César. Os Leigos e o Poder. São Paulo: Editora Ática, 1986.

ELIADE, Mircea. O sagrado e o profano: a essência das religiões. São Paulo: Martins Fontes, 2001.

LEVÊQUE, Pierre. O papel da Religião na Gênese das Cidades. LPH: Revista de História, Ouro Preto, n.4, pp. 14-25, 1993/1994.

HERVIEU-LÉGER, Danièle. O peregrino e o convertido: a religião em movimento. Lisboa: Gradiva, 2005.

HOLANDA, Sérgio Buarque de. Raízes do Brasil. 26. ed., São Paulo: Companhia das Letras, 1995. HOORNAERT, Eduardo. A Igreja no Brasil-colônia (1550-1800). São Paulo: Brasiliense, 1982. . Formação do Catolicismo Brasileiro (1550-1800). Petrópolis: Vozes, 1991. . (Coord.) História da Igreja no Brasil. Primeira Época. Petrópolis: Vozes, 1992. 
LONDOÑO, Fernando Torres (org.). Paróquia e Comunidade no Brasil: perspectiva histórica. São Paulo: Paulus, 1997.

MARX, Murilo. Nosso chão: do Sagrado ao Profano. São Paulo: EDUSP, 1988.

. Cidade no Brasil, Terra de Quem? São Paulo: Nobel/EDUSP, 1991.

NASCIMENTO, José Anderson. Sergipe e seus monumentos. Aracaju: J. Andrade, 1981.

PRIORE. Mary Del. Religião e Religiosidade no Brasil Colonial. São Paulo: Ática, 1994.

OLIVEIRA, Pedro A Ribeiro de. Religião e dominação de classe: gênese, estrutura e função do catolicismo romanizado no Brasil. Petrópolis: Vozes, 1985.

RAMINELLI, Ronald. Símbolos do espaço urbano colonial. In: VAINFAS, Ronaldo (org.) América em Tempo de Conquista. Rio de Janeiro: Zahar, 1992, pp. 163-175.

. História Urbana. In: CARDOSO, Ciro Flamarion; VAINFAS, Ronaldo (orgs.). Domínios da História. Ensaios de Teoria e Metodologia. Rio de Janeiro: Campus, 1997, pp. 185-202.

REIS, João José. A morte é uma festa: ritos fúnebres e revolta popular no Brasil no século XIX. São Paulo: Companhia das Letras, 1991.

ROCHA, Manuel Ribeiro. Etiope Resgatado. Discurso teológico-jurídico sobre a libertação dos escravos do Brasil de 1758. Petrópolis: Vozes/; São Paulo: CEHILA, 1992.

SANTOS, Francisco José Alves dos. Espaço e Distintividade: Igreja de Nossa Senhora do Rosário de Estância, Igreja de Elite. GEONORDESTE, Aracaju, Ano II, n. 2, Ago/1985, pp.63-8, 1985.

- A Igreja de Nossa Senhora do Rosário de Estância: Religião e Diferenciação Social. Cadernos de Cultura do Estudante, Aracaju: PROEST, n.01, pp. 39-40, 1984.

. Igreja de Nossa Senhora do Rosário de Estância - Notas para a sua História. Aracaju: $\overline{\mathrm{PDPH}} / \mathrm{UFS}, 1988$.

. Estância: fontes para a sua História. Aracaju: mimeografado, 1988.

. Calendário Religioso da Irmandade de Nossa Senhora do Rosário de Estância 1772-1827. Revista do IHGS, Aracaju, n.31, 1992, pp. 69-81.

\section{NOTAS}

\footnotetext{
${ }^{1}$ Parte integrante da monografia apresentada junto ao curso de Licenciatura em História em outubro de 1998, sob a orientação da Profa. Msc. Verônica Maria Menezes Nunes, a quem agradeço minha iniciação nos estudos sobre o fenômeno religioso.

${ }^{2}$ Tradição bem antiga, este significou numerosos arranjos que instrumentalizaram a Igreja Católica e determinou seu atrelamento em relação ao Estado.

"Portugal como senhor dos mares 'nunca dantes navegados', organizador da Igreja Católica em termos de conquista e redução, planificador da união entre missão e colonização.” (HOONAERT, 1992, p.35)

${ }^{3}$ Isto estava relacionado ao caráter cruzadístico do catolicismo luso no momento da conquista das terras do Novo Mundo (HOONAERT, 1991, p.33).
} 
4 "Além de regularem a administração das irmandades, os compromissos estabeleciam a condição social ou racial exigida dos sócios, seus deveres e direitos" (REIS, 1991, p.50).

${ }^{5}$ As mais prestigiosas, por exemplo, exigiam em geral de seus membros, além do sucesso material, que pertencessem à raça dominante" (REIS, 1991, p.53).

${ }^{6}$ Escritura de doação das terras da cidade da Estância feita por Pedro Homem da Costa e sua mulher Méssia Cardoza, a Nossa Senhora de Guadalupe, que se acha no cartório do escrivão João Moreira de Magalhães na referida cidade (Apud. SANTOS, 1988, p.7).

7 Este aspecto majestoso apontado pode ser confirmado em descrições recentes, como a de José Anderson do Nascimento: "Seu frontispício é formoso, apresenta duas torres bem delineadas, com sineiras em arco pleno. O frontão é ordelado e aberto, com um óculo e encimado por uma cruz. Abaixo da cimalha, na parte central, três janelões, excelentemente dimensionados, com pardieiros encurvados. Três portas almofadadas, com vergas em arco pleno, dão acesso ao interior do templo, que se destaca pela ampla nave central, ladeada por corredores" (NASCIMENTO, 1981, p.72).

${ }^{8}$ Informação obtida no artigo "O aniversário da Irmandade do Santíssimo Sacramento". PARÓQUIA DE NOSSA SENHORA DE GUADALUPE. Livro de Recortes de Jornais. Estância, s.d.

${ }^{9}$ Em relação a determinação de ser branco há uma ressalva em um ofício enviado pelo Vigário-Geral e Delegado José Francisco de Meneses Sobral, destinada ao Presidente da Província Luís Antonio Pereira Franco, datada em 10 de agosto de 1853 .

${ }^{10}$ Isto pode ser constatado na Petição feita em 31 de março de 1842 à viúva do Major Antonio Carvalho de Sousa, pelo então tesoureiro José Eustaquio da Silva (Ver: AJES, Fundo: Cartório Estância $2^{\circ}$ Ofício, Série Cível, Sub-série Justificação Cível, Caixa 08, 1840-1842).

${ }^{11}$ Este pensamento pode ser melhor observado na obra Etíope Resgatado, do padre Manuel Ribeiro da Rocha, que se constitui numa importante fonte na busca de informações sobre o quadro tétrico da escravidão no Brasil. O autor assume a defesa dos negros, propondo a via média da libertação dos cativos após 20 anos de serviço. Entretanto, quando trata do comércio de escravos, faz prevalecer a escravidão como método de evangelização. Defende o princípio “é melhor um cristão escravo do que um pagão livre". O negro ao desembarcar nas costas brasileiras trazia caracteres demoníacos herdados da sociedade africana, que deveriam ser eliminados com a conversão ao cristianismo (ROCHA, 1992, p.52).

${ }^{12}$ Outras informações podem ser obtidas em DANTAS, Beatriz Góis. A Taieira de Sergipe. Pesquisa exaustiva sobre uma dança tradicional do Nordeste. Petrópolis: Vozes, 1972; . Taieira. Aracaju: SEC, 1976. (Cadernos de Folclore Sergipano); MORAIS FILHO, Melo. A Procissão de São Benedito em Lagarto. Aracaju: SEC, s.d. (Cadernos de Folclore Sergipano).

${ }^{13}$ Conforme atesta a ata da reunião dos Irmãos em 1780 (Ver: Ata da União das Irmandades de Nossa Senhora do Rosário e São Benedito - 1780. Livro de Provimentos e Capítulos de Visita da Irmandade de Nossa Senhora do Rosário. Estância, p. 05 - Arquivo da Casa Paroquial de Estância. Apud. SANTOS, 1988, p.13.

${ }^{14}$ Como a doação do Sítio Pedras, pelo Capitão-Mor Manoel Francisco da Cruz e Lima, em 1784. Ver: Certidão de Escritura. Livro de Provimentos e Capítulos de Visita da Irmandade de Nossa Senhora do Rosário. Estância, p. 05 Arquivo da Casa Paroquial de Estância (Apud. SANTOS, 1988, p.30).

${ }^{15}$ Há dois ofícios que tratam da invasão do cemitério. Um do sacristão da Irmandade (Ofício de Manoel Pereira Rosa Junior ao Vigário Eliziario Vieira Muniz Telles. Laranjeiras, 15 abr. 1883. APES, Ag4-clero, cx. 28, doc. 034) e outro do provedor do cemitério (Ofício de Antonio Agostinho Ribeiro Guimarães ao Vigário Eliziario Vieira Muniz Telles. Laranjeiras, 15 abr. 1883. APES, Ag4-clero, cx. 28, doc. 034.)

Artigo recebido em 03/2010. Aprovado em 04/2010. 